\title{
A könyvtár és a digitális gyüjtemények az elektronikus közszolgáltatások rendszerében
}

Az Európai Unió a könyvtári adatbázisok és elektronikus katalógusok online elérhetőségének biztosítását a tizenkét legfontosabb állampolgári közszolgáltatások egyikeként definiálja, azonos szinten egy ember életének legfontosabb közjogi aktusaival. Ez a szemléletmód még nem tapasztalható elég határozottan a kulturális irányítás, az országos és helyi döntéshozók részéről, s talán maga a könyvtári menedzsment sem érzékeli még kellőképpen ennek előnyeit. A tanulmány megállapításai szerint a könyvtár a legtágabb értelemben vett információszolgáltatás és ismeretszervezés terén megvalósított innovációkkal hozzájárulhat a közszolgáltatások megújításához, szélesítve a digitális közigazgatás lehetőségeit, s egyben új értékpontokat kínálva a hálózati kultúra rendszerében.

Kulcsszavak: Könyvtár, digitális gyűjtemények, elektronikus közigazgatás

Szerzői információ:

Kerekes Pál

Informatikus könyvtáros az ELTE-n végezte tanulmányait. 2009-ben doktorált. 1994-tól információs tanácsadóként dolgozott az Elender, a Microsoft, a Compaq és a Minolta cégek magyarországi leányvállalatainál. Parlamenti konzultánsként részt vesz az internettel kapcsolatos törvények elókészítésében és szakmai vitáiban. 2003-tól 2007-ig a Magyar Televíziót felügyeló kuratórium elnökségi tagja. 2005-tól az ELTE Informatikai és Könyvtártudományi Intézetének oktatója. Rendszeresen publikál napilapokban és online szakmai kiadványokban. Kutatási területe az elektronikus olvasáskultúra, ezen belül kiemelten az e-könyvtár és az e-kormányzat összefüggései.

Így hivatkozzon erre a cikkre:

Kerekes Pál. „A könyvtár és a digitális gyüjtemények az elektronikus közszolgáltatások rendszerében.” Információs Társadalom IX, 3. szám (2009): 67-84.

= https://dx.doi.org/10.22503/inftars.IX.2009.3.4


Kerekes Pál

\section{A könyvtár és a digitális \\ gyújtemények az elektronikus közszolgáltatások rendszerében}

Felvetések, vitapontok, programelemek ${ }^{1}$

A 21. század elsố évtizedében a magyar Országgyúlés eddig két-három évente tárgyalt informatikai tárgyú elôterjesztéseket. A legutóbbi parlamenti szezonban azonban felgyorsult a munka: 2008 ószén és 2009 tavaszán is készültek törvényjavaslatok, még ha végszavazásukra csak vontatottan került is sor, vagy az még meg sem történt. Az elektronikus közszolgáltatásokról (T/6767), majd a hivatalos iratok elektronikus kézbesítéséról és az elektronikus tértivevényról (T/9024) szóló elóterjesztések benyújtása érzékelhetơvé teszi a törvényhozói aktivitás növekedését. A hálózati világ szabályozásra vár - gondolhatnánk ebból is: a tény inkább az, hogy a valóság, a mindennapi élet igényli a digitális reform irányába tett lépéseket. Az átalakuló életformák, munkavégzési alapszerkezetek kikényszerítik az új törvényi kereteket. Nem az informatikát kell tehát regulázni, mint sokan hiszik és terjesztik, hanem az informatizálódás nyomán születố új értékeket, társadalmi formatárakat szükséges jogi módszerekkel is megalapozni.

Mindkét törvényjavaslat évezredes struktúrák felváltásáról intézkedne. Az elektronikus közszolgáltatásokról szóló elốterjesztés 5. paragrafusa például kimondja: „Az elektronikus közszolgáltatások nyilvános és tájékoztató jellegú szolgáltatásainak elérése nem korlátozható.” Ez a végtelenül egyszerú mondat végtelenül bonyolult kommunikációs szerkezetekre utal. Az elektronizáció alapján és annak folyamatos hatására találkozhat egymással két régen használt, de eddig nem vagy csak nagyon ritkán öszszekapcsolt fogalom: a közigazgatás és az információellátás. Vagy mondhatjuk úgy is: a központi és az önkormányzati tevékenység, illetve a hozzá tartozó tájékoztatás és a tájékozódási lehetôség. Mára egy eszmekörbe tartozónak véljük ezeket a fogalmakat, a digitalizáció és a hálózatiság megteremtette a tartalmi összefüggéseket. Ebben a rendszerben már nem válnak el egymástól az egykor nagyon távoli ügyintézési és ügyféltájékoztatási formák.

Az elektronikus kézbesítést lehetôvé tevố joganyag 2. paragrafusa rögzíti: „Az Állami Elektronikus Kézbesítési Szolgáltató e feladatának ellátása érdekében - külön jogszabályban foglaltak szerint - elektronikus kézbesítési tárhelyet tart fenn, amelyhez a kézbesítési folyamatban részt vevố feladó és címzett számára biztosítja a hozzáférést." Nem a levél utazik tehát, nem a postás és a mögötte álló hivatali szervezet mozgatja a közleményeket, hanem monitorokról monitorokra kerülnek a karakterek, az életfundamentumokat érintố, teljes jogi arzenállal biztosított tartalmak. Ez az átalakulás természetesen gyökeresen átformálja az archiválás és a visszakeresés évezredes metódusait.

\footnotetext{
${ }^{1}$ A tanulmány az egyezó címú doktori disszertáció rövidített, egyes részeiben aktualizált változata.
} 
Mindkét szemelvénnyel csak azt kívántam érzékeltetni, hogy az elektronikus közigazgatás - más szóval: az elektronikus kormányzat, még egyszerúbben: az adminisztráció - új dimenziókba tevốdik át, vadonatúj virtuális keretek közé kerül. A változások nyomán új szervezetek keletkeznek, és a meglevók átalakulnak. Ebból az aspektusból fontos, hogy a közpénzekból fenntartott intézménykomplexum minden tagja, így a könyvtárak is tanulmányozzák, vizsgálják viszonyukat az elektronikus közszolgáltatások normarendszeréhez, hálózati szervezetéhez, virtualizációs köreihez. Hangsúlyozni szeretném, hogy itt nem a könyvtárak általános modernizációjáról, annak problémahalmazáról van szó. A bibliotékák, az évezredek alatt folyamatos változásokra kényszerült tudástárak az informatika korában is kiérlelték az ismeretreprezentáció és ismeretszolgáltatás megfelelő technikáit.

Írásom célja az, hogy a bibliotéka fogalmát a lehetô legtágabban értelmezve, a közszolgáltatások elektronikus válfajainak fokozatos kialakulásával, illetve a hálózati ügyintézés térnyerésével létrejövố e-közigazgatási rendszerben mutassa be a könyvtárt mint a kialakuló új digitális igazgatási és önkormányzati infrastruktúrák versenyében létezố szervezetet. Egészen konkrétan azt vizsgálom, hogy az elektronikus kormányzat fogalomkörébe hogyan kapcsolódik a könyvtár mint a tudástársadalom információs közintézménye, az ismeretorganizáció hálózatának egyik megszervezóje és múködtetôje. Úgy vélem, a formálódó hazai tudástársadalom elektronikus terei nem választhatók szét mereven. A digitális társadalom fejlódésének mozzanatai - ellentétben az előzố korszakok szigorú határok közé szorított köztevékenységi mintáival - fedik egymást, többnyire egymásra épülnek, így az összefüggések és kölcsönhatások vizsgálata termékeny és hasznos lehet az érintett területeken, különösen a feladatmegosztás észszerú kialakítása és a párhuzamosságok, a különféle projektek között sokszor fellelhetố rivalizálás elkerülése szempontjából. Az intelligens közigazgatási terek létrehozásának és múködtetésének természetes közege lehet a funkcionálisan jól múködô, tudásmenedzselő könyvtár, ahol egy helyen adott a múvelődést, a rekreációt és a tanulást, általában a humán minôséget megalapozó ismeretanyag, valamint az internet-eróforrások igénybevételének teljes technikai bázisa is.

Dolgozatom nem foglalkozik az e-kormányzat helyzetének és trendjeinek bemutatásával. Erre nézve bớven áll rendelkezésre megfelelő dokumentáció, elég utalni az ITTK tevékenységére, a Corvinus Egyetem kutatóinak munkájára és a megfelelő kormányzati (EKK) munkaanyagokra.

\section{Hipotézisek, könyvtári értékpontok}

1. A papírról leválasztott, de egyelớre még túlnyomórészt a betúre épülő elektronikus formatár - az internet - múvelődéstechnikai birtokbavétele bonyolult és összetett folyamat. Az eredményekben, a pozitív változásokban a könyvtárak döntô szerepe nem vitatható. Minden kezdeményezés, amely az elektronikus bibliotéka szolgáltatásainak bôvülését kutatja, kísérleti úton is, fontos lehet az egész könyvtári rendszer jövớje szempontjából. A könyvtárt mint az európai direktívák által azonosított elektronikus közszolgáltatások egyik territóriumát eddig még kevéssé vizsgálták Magyarországon, ezért az ilyen irányú kutatások véleményem szerint pozitívan befolyásolhatják a jelenleg is szükségképpen zajló könyvtári funkcióváltások elfogadottságát. 
2. Az információs és emlékezetbázisok, általános és szakarchívumok missziós célkitúzéseikben általában megjelölik, hogy tempóveszteség nélkül igyekeznek megfelelni az új, többnyire elektronikus alapú felhasználói igényeknek, illetve a digitális kínálat bôvüléséból következô fejlesztési elvárásoknak. Ez száguldó iramú, rohamos érték- és mintaváltásokkal járó folyamat, amelyben a hálózati kultúra normarendszerének kialakítása és megszilárdítása az e-demokrácia alapformáinak ismeretét és használatát feltételezi. Ebben az összefüggésben is szükséges a könyvtárak hivatását, szerepét és lehetôségeit vizsgálni.

3. A hálózati kultúra jövốje - ezt talán kevesen vitatják - a minôségtól, a kvalitásos digitális termékek befogadásától és azok terjesztési mechanizmusának meggyökereztetésétôl függ. Ehhez kezdetben társadalmi eróforrások igénybevétele szükséges támogatási ösztönzớrendszer kialakítása és múködtetése mellett. Ebból az aspektusból az elektronikus közigazgatásnak a könyvtári rendszerhez kapcsolható elemei a támogatás forrásaiként és lehetốségeiként vehetốk számba.

4. A jelenleg érvényes digitális stratégiák célja, hogy meghatározzuk az elektronizációval szinte korlátlanná váló elérhetôség bơvülésének távlatos kivezetését, vagyis megtervezzük új rétegek, akár tömegek információellátásának koncepcióját és menetrendjét. Szorosan ide tartozik - dolgozatom témája is ez - az elektronikus közszolgáltatások megismertetése és használatuk elôsegítése az információmenedzsment eszközeivel, elsốsorban könyvtári értékpontokat kínálva, és nem kis részben a digitális ismerettárak rendszerbe vonását javasolva.

5. A kormányzat és az adminisztratív közintézmények jellegükból és funkciójukból fakadóan fóként adat-, információ- és tudástárak múködtetésével töltik be hivatásukat (feladatuk többek között az állampolgárokra vonatkozó társadalmi, üzleti, piaci, jogi és politikai jellegú adatok és információk gyújtése, feldolgozása és nyilvántartása, a jogalkotás és szabályozás), és munkájuk eredményei is nagyobbrészt információ vagy tudás formájában kerülnek nyilvánosságra. A közigazgatás ezeknek az adatoknak nem csupán felhasználója, hanem tulajdonosa is. Így nincs akadálya annak, hogy a hagyományos közigazgatási folyamatok újragondolása és átszervezése a tudás elosztásának és megosztásának új formáit hozza létre, akár az átalakuló könyvtári intézmények és szolgáltatások keretein belül is.

\section{E-könyvtár és e-közigazgatás: alkalmi kapcsolat vagy szervezeft összekapcsolódás?}

A 2008. évi könyvfesztiválon vitát rendeztek a könyvtárak jövójéról. A „Hírszerzô’ portál így számolt be az eseményról: „Ismét beszélgetésen jártunk, ahol Csepeli György szociálpszichológust, György Péter esztétát és Harsányi Lászlót, a Nemzeti Kulturális Alap vezetôjét ültették egy asztalhoz a magyar könyvtárosok. A meghirdetett cím „A kultúra metamorfózisa” volt, s a résztvevók a könyvtáraknak az információs társadalomban játszott szerepéról diskuráltak: „A könyvtárak új szerepét illetôen nincs is vita. Ennek a lényege az, hogy a könyvtári hálózatot modern információs központok hálózatává kell átalakítani. Olyan intézmények hálózatává, ahol nemcsak könyvet kölcsönözni és folyóiratokat olvasni lehet, hanem - különösen vidéken, a kis falvakban 
- lehetôség van a széles sáv adta összes pozitívum, például az elektronikus ügyintézési formák kihasználására, illetve a kötelezettségek teljesítésére.”2

A három vezetô, véleményformáló szakember teljesen egyetért abban, hogy a szükségszerú könyvtári (természetesen elsôsorban közkönyvtári) átalakulás egyik iránya lesz - vagy még inkább lehet - az elektronikus közszolgáltatások rendszerintegrációjában való szerepvállalás, funkciógyújtés, illetve beágyazódás. Le kell azonnal szögezni, hogy ez nem valami kizárólagosságot jelent, nem értelmezhetố úgy, hogy a könyvtárak funkcióbővülésének egyetlen vagy legfóbb elektronikus „terepe” az e-kormányzat volna. Csak arról van szó, hogy az e-közigazgatás fontos szegmense az információs társadalomnak, a digitális szolgáltatások hatalmas fogyasztója. Az ilyen igények kiszolgálására sokan kívánnak vállalkozni, persze különbözố megalapozottságú kompetenciákkal. A könyvtárak részvétele ebben a versengésben, tekintettel a rendszer eddigi vitathatatlan eredményeire, hasznos és sikeres lenne, növelné az egész szakma elfogadottságát és az e-bibliotékák hálózatának teljesítóképességét. Itt kell megemlíteni több e-közszolgáltatási projektet, amelyek - részben vagy egészben - könyvtári intézményekre vagy könyvtári szolgáltatásokra épülve indultak meg, illetve múködnek ma is. Ezek (nem fontossági sorrendben) a következók:

- teleház,

- TSR - Többcélú Szektorközi Rendszer,

- e-Magyarország Pontok,

- EU (parlamenti és bizottsági) tájékoztatási és dokumentációs intézmények,

- e-befogadás program.

\section{Kitekintés: a könyvtárak és az e-kormányzat együttmüködése az Egyesült Államokban}

Kovácsné Koreny Ágnes több publikációjában³ mutatja be az amerikai könyvtárosok elektronikus közszolgáltatási tevékenységét. Írásai rámutatnak, hogy sok tekintetben stabil kapcsolat és tartalmi együttmúködés alakult ki a közkönyvtárak és az e-közigazgatás intézményei között. Az ottani könyvtárak természetesen más társadalmi viszonyok között, eltérố történelmi hagyományok alapján múködnek, néhány megállapítás, észrevétel és állásfoglalás azonban a mi körülményeink között is érdekes és inspiratív lehet. A szerző összefoglalóan megállapítja: „Az amerikaiak jelentős része - vagy azért, mert nincs más lehetôségük a kapcsolódásra, vagy pedig azért, mert segítségre szorulnak a számítógép, illetve a világháló használatát illetoóen - csak a könyvtárakban elérhetố ingyenes internet-hozzáférésre számíthat. Számos közigazgatási szerv egyenesen a legközelebbi közkönyvtárba irányítja az állampolgárokat az elektronikus

\footnotetext{
${ }^{2}$ Kiss Ádám 2008: Internetadó és vidéki könyvtárak: alapjaiban hibás a magyar kultúrafinanszírozás. [Elektronikus dokumentum] In Hirsæeræó, ápr. 28. http://www.hirszerzo.hu/cikk.eleg_az_alsagos_liberalis_ anything_goes-bol.64587.html

3 Kovácsné Koreny Ágnes: E-kormányzat az amerikai közkönyvtárakban. Szakirodalmi szemle. Tudományos és Mǘszaki Tájékoztatás, 56. évf., 2009, 4. szám, 178-189.

Kovácsné Koreny Ágnes 2008: Közkönyvtárak, értékek, bizalom és e-kormányzás. Tudományos és Müszaki Tájéko:tatás, 55. évf., 11-12. szám., 553-556.
} 
kormányzati eszközök igénybevétele céljából. S a könyvtári szolgáltatás utóbbi eleme az, amellyel egyetlen más intézményhálózat sem versenyezhet: a könyvtárak ingyenes számítógép-használatot, ingyenes internethasználatot, s ingyenes szakmai segítséget kínálnak a hozzájuk fordulóknak. Mindehhez adódik még a könyvtáraknak a helyi közösségek életében betöltött meghatározó szerepe s az állampolgárok közkönyvtárakba vetett, történelminek mondható bizalma."

Az amerikai közkönyvtárak e-kormányzati szolgáltatásainak néhány, hazai feltételek között is értelmezhetô jellemzójét érdemes felidézni:

A könyvtárak e-kormányzati információs pontokká fejlődése a könyvtárak elôzetes szándéka nélkül következett be, anélkül, hogy az új társadalmi szerepükkel kapcsolatos döntésekbe bevonták volna óket.

A fenntartók és a hatóságok elvárják a könyvtáraktól, hogy e-szolgáltatásokat nyújtsanak az állampolgároknak.

A könyvtárak az új e-kormányzati szolgáltatásokat anélkül kínálják, hogy ahhoz költségvetési forrásokat, további személyzetet vagy akár csak képzési támogatást kapnának.

A jövőre nézve feltétlenül szükséges, hogy

- a könyvtárak nagyobb szerepet kapjanak az e-kormányzati szolgáltatásokkal, valamint a vész- és katasztrófahelyzetekben nyújtandó hatósági tevékenységekkel kapcsolatos tervezési és döntéshozatali folyamatokban az államigazgatás valamennyi szintjén;

- az új szolgáltatásokhoz kapjanak a közkönyvtárak többletforrásokat;

- az e-kormányzattal kapcsolatos könyvtári szolgáltatások finanszírozásába vonjanak be alternatív forrásokat is;

- induljanak kutatások az egyének és a közösségek elektronikus kormányzati szükségletei, illetve azok kielégítése tárgyában, valamint arról, hogy az új könyvtári szolgáltatások milyen hatással vannak az egyénekre, a közösségekre és magukra a könyvtárakra;

- a könyvtárak hatékonyabban kommunikálják mind a köz-, mind a magánszféra felé, hogy milyen e-kormányzati szolgáltatásokat nyújtanak, és alaptevékenységeiken túl mi mindent tesznek vész- és katasztrófahelyzetekben;

- kapjon helyet már a könyvtárosképzésben is az e-kormányzati szolgáltatások használata.

\section{Portálok a közigazgatás szolgálatában: Jelen vannak a könyvtárak is?}

Az Európai Unió különbözó e-kormányzati irányelvei (eEuropa 2005, i2010) az elektronikus közszolgáltatások húsz csoportját definiálják. Ezekból Magyarországon a kormányprogramokban és pályázati struktúrákban különbözố alpontokkal bóvítve huszonhét lett, megórizve az eredeti számozást, de figyelembe véve a terminológiai és szervezeti különbségeket. Az állampolgárok számára nyújtott szolgáltatások - nem említve itt a vállalkozásokra irányulókat - a következók: 
1. Jövedelemadó: bevallás, értesítés a kivetett adóról.

2/a. Álláskeresés a munkaügyi központokon és az interneten keresztül az ÁFSZ állásajánlataiban.

2/b.Álláshirdetés az interneten keresztül az ÁFSZ adatbázisában.

3/a. Munkanélküli járadékok.

3/b.Gyermekek után járó pótlékok.

3/c. Gyógyászati költségek (visszatérítés vagy közvetlen kifizetés).

3/d. Tanulói ösztöndíj-lehetôségek.

4/a. Útlevéligénylés és útlevéllel kapcsolatos egyéb ügyintézés.

4/b.Gépjármúvezetối engedélyek ügyintézése, vezetési jogosultság megszerzése.

5. Jármú-nyilvántartási ügyintézés, jármúigazgatás (új, használt és importált gépjármúvek forgalomba helyezése, múszaki vizsgálata, jármúigazgatási ügyek).

6. Építési engedélyek kérelmezése.

7. Rendôrségi bejelentések (pl. lopás esetén).

8. Közkönyvtárak (katalógusok, keresési lehetóségek elérése).

9/a. Születési bizonyítványok ügyintézése: kérvényezés, kiadás.

9/b.Házassági bizonyítványok ügyintézése: kérvényezés, kiadás.

10. Beiratkozás felsôoktatási intézményekbe.

11. Lakcímváltozás bejelentése (lakcímigazolványok pótlása, cseréje).

12. Egészségi ellátással összefüggó szolgáltatások (pl. interaktív tanácsadás kórházi szolgáltatások elérhetőségéról, kórházi bejelentkezések).

A felsorolásból világosan és egyértelmúen látszik, hogy az EU az elektronikus adatbázisokhoz való könyvtári hozzáférést alapvetố elektronikus közszolgáltatásként értékeli, azonos szinten egy ember életének talán legfontosabb közjogi aktusaival. A legfrissebb Kék Notesz ${ }^{4}$ megemlíti, hogy a mentorokkal kapcsolatba lépó kliensek a vizsgálatot megelőzố három hónapban a fentiek közül minden második esetben igénybe vették az alábbi hatot:

- álláskeresés a munkaügyi központokon keresztül (78 százalék),

- felsôoktatási intézménybe való jelentkezés (74 százalék),

- nyilvános könyvtárak elérése (72 százalék),

- személyi jövedelemadóval kapcsolatos ismeretek, online adóbevallás (72 százalék),

- személyi iratok, pl. útlevél, jogosítvány igénylése (64 százalék),

- egészségügyi szolgáltatások (50 százalék).

A könyvtári rendszerekbe való belépés igénye, az ott elérhetố adatbázisok használatának szükséglete véleményem szerint mindenképpen azt jelenti, hogy a meghatározó e-közigazgatási portálokon meg kell jelenniük a könyvtári boxok elérési útvonalainak. A legnagyobb ügyfélszámot felmutató portálokon (kormányzati portál, Budapest portál) azonban - legalábbis jól érzékelhetốen - nemigen funkcionálnak a tájékoztatási felületek, online adattárak.

${ }^{4}$ Diosy Tamás - Enyedi Nagy Mihály - Molnár Szilárd - Z. Karvalics László 2009: Kék notesz, 2009. A 10. Internethajó helyzetjelentése. Budapest, közreadja az ENAMIKÉ és az eWorld. Készítette az ITTK és a GKIeNET kutatócsoportja, 42. http://internethajo.hu/pdf/keknotesz2009.pdf 


\section{Az elektronikus ügyintézés szolgáltatói szintjei}

Az e-közigazgatás múködési módszertanának, gyakorlatának és különbözó mintáinak megismerése a közszférában dolgozók, így a könyvtárosok számára is szükségesnek látszik. Elsôsorban azért - így tapasztaltam a dolgozat elókészítése során folytatott konzultációkon -, mert az elektronizáció nyomán az állampolgár és a hivatalok viszonya látványosan és mélyrehatóan átformálódik. A változások követése nélkül pedig - tekintettel az átalakuló közszolgáltatásokra - egy adott környezetben maga a könyvtár is önmeghatározási pánikhelyzetbe kerülhet, illetve nehézségekbe ütközhet maga a tájékoztatás is, hiszen teljesen új kérdéskörök, új magatartások merülhetnek fel.

Az elektronikus közigazgatás múködési modellje, rendszere és formái az öt szolgáltatási szint leírásán keresztül tekinthetók át:

1. Információs, tájékoztató szolgáltatás, amely csak általános információkat közöl az adott üggyel kapcsolatos teendókról és a szükséges dokumentumokról.

2. Egyirányú interakciót biztosító szolgáltatás, amely az 1. szinten túl az adott ügy intézéséhez szükséges dokumentumok, nyomtatványok letöltésére és azok ellenốrzött vagy ellenôrzés nélküli elektronikus kitöltésére ad módot; a dokumentum benyújtása hagyományos úton történik.

3. Kétirányú interakciót biztosító szolgáltatás, amely közvetlenül vagy ellenốrzés mellett kitöltött dokumentumok segítségével elektronikus adatbevitelre és a bevitt adatok ellenôrzésére nyújt lehetôséget. Az ügy indításához és intézéséhez személyes megjelenés nem szükséges, de az ügyhöz kapcsolódó közigazgatási döntés közlése, valamint a kapcsolódó illeték- vagy díjfizetés hagyományos úton történik.

4. Teljes mértékben online lebonyolítható ügyintézési folyamatot biztosító szolgáltatás, melynek igénybevételekor az ügyhöz kapcsolódó közigazgatási döntést is elektronikus úton közli a hivatal, és a kapcsolódó illeték- vagy díjfizetés elektronikus úton is intézhetô.

5. Targetizációt, proaktivitást és perszonalizációt biztosító szolgáltatás, amelyben az ügyfél már teljes körúen hozzájut a szolgáltatáshoz úgy, hogy csak új információt tartalmazó adatot kell szolgáltatnia. Egyetlen olyan adatot sem kell újra megadnia vagy hitelesítenie, amelyet korábban bármely kormányzati szervvel már közölt. Az ügyfél az egész e-közigazgatási rendszerrel áll kapcsolatban, nem csak egy hivatallal. (Ezt a szintet 2006-ban vezették be.)

Ezek a szintek - itt most nem részletezett további specifikációkkal - alkalmasak arra, hogy egy ország felkészültségét és állapotát bemutassák az e-közigazgatás szempontjából. Az EU ilyen standardizáció alapján évente végez felméréseket a tagországokban. Itt csak annyit érdemes kiemelni, hogy a 2006-os adatok szerint a könyvtári szolgáltatások, amelyek a négy csokorra bontott húszféle szolgáltatás közül az ismételten igénybe vett szolgáltatások körébe tartoznak, az e-közigazgatási kiadások és beruházások tekintetében az utolsó helyen állnak, jelentôsen elmaradva a másik három csokortól, amelyekbe - „erốsorrendben” - a jövedelemgeneráló szolgáltatásokat, a regisztrációs szolgáltatásokat és a különféle engedélyek és jogosítványok megszerzését sorolták. Érdekes adat továbbá, hogy az 5. szolgáltatási szint teljesítése (perszonalizáció, 
targetálás: a könyvtári szolgáltatás itt a második helyen van) az EU 25 országában átlagosan 39 százalékos, míg Magyarország készültsége csak 11 százalékos. $^{5}$

\section{Könyvtár: kulturális vagy az információs társadalom szektorához tartozó intézmény?}

A felmérések és egyéb vizsgálatok folyamán a terminológiai és fogalmi bizonytalanságok miatt rendkívül nehéz az egyes országok e-közigazgatás tevékenységének összehasonlítása. Az EU ezért sok esetben felállítja saját rendszereit. A könyvtári világ szempontjából nagyon lényeges, hogy egyáltalán hová sorolják a könyvtári tevékenységet. Az EU rendszerében a könyvtári munka - meglepó módon, ha ez valakinek még meglepetés - nem a kulturális tevékenységek csoportjába, hanem az információs társadalom szektorába tartozik. Ezt az osztályozást követi az EU-portál rendszere is, ahol a jól elkülöníthetố tevékenységek felsorolásában a könyvtár az „információs társadalom” kategóriában szerepel. ${ }^{6}$ A téma jelenlegi felügyelôje, Viviane Reding feladatkörének a megnevezése is ,az információs társadalommal kapcsolatos és médiaügyekért felelôs biztos". ${ }^{7}$ Véleményem szerint ez természetesen nem azt jelenti, hogy a könyvtár ma már csakis informatikai tevékenységnek tekinthetố, de azt mindenképpen jelzi, hogy a gyújteményszemléletú bibliotéka intézménykarakterét - legalábbis az európai jövóképben - a szolgáltatási irányultságú elektronikus információs központ missziója váltotta fel.

Az e-kormányzat és az e-demokrácia két jól elkülönülő fogalom. Ennek ellenére a közvélemény és gyakran a dokumentummenedzsmenttel foglalkozó intézmények (könyvtárak, archívumok és levéltárak) szakmai munkatársai is nehezen igazodnak el a két terminus jelentésárnyalataiban. Ez érthetố is, hiszen ezek a tevékenységek napi szinten hatnak és visszahatnak egymásra, elektronikus felületeiket gyakran a politika, vagyis a kormányzat, illetve a helyi közigazgatás vezetô személyiségeihez kötik. Ezt az összefüggésrendszert ez a tanulmány természetesen nem taglalja. A mi szempontunkból itt most az a lényeges, és ebben mindenki egyetért, hogy az e-demokrácia alapja a megfelelő szintú, akár a döntéshozatalhoz szükségessel azonos mélységú és kiterjedésû tájékoztatás, elsôsorban elektronikusan prezentált, feldolgozott és kereshetôvé tett szövegdokumentumok segítségével. Ez pedig tipikusan könyvtári feladat. Mégis azt látjuk, hogy az Országgyúlés vagy Budapest honlapján elérhetố testületi iratok - parlamenti terminológiával élve: „irományok” - szolgáltatását nem könyvtári szervezetból végzik. Ez érzékelhetố is, hiszen csak maga a dokumentálás, a rögzítés korrekt, míg a hozzáférés segítése, a tartalmi és formai feltárás nagyon szúkös, akár teljesen hiányozhat. Az alcímben feltett kérdés tehát ismét felmerül: az e-kormányzati tájékoztatás digitális tartalomszolgáltatási feladat vagy pedig könyvtári hagyományokon alapuló, akár az információkeresésre alkalmas (mesterséges vagy természetes) nyelvekre is ráépüló, tartalomfeltáró tevékenység? Jelenleg úgy látszik, hogy informatikai projektként ér-

\footnotetext{
${ }^{5}$ Molnár Szilárd - Borovitz Tamás - Csótó Mihály - Nyáry Mihály - Rab Árpád - Székely Levente: Elektronikus közigazgatás éves jelentés, 2007. Budapest, BME ITTK Kutatócsoport, a Bell Research Kutatócsoport szakmai partnerségével, 20-22. http://www.ittk.hu/web/docs/ITTK_EKOZIG_2007.pdf

${ }^{6}$ http://ec.europa.eu/information_society/activities/digital_libraries/index_en.htm

${ }^{7}$ Honlapjának címe: http://ec.europa.eu/commission_barroso/reding/index_en.htm
} 
telmeződnek a közigazgatási adatvagyon prezentálását célzó fejlesztések, intézményalapítások. Van ellenpélda is: Nagykốrös település e-praxisán keresztül látható, hogy a könyvtári szempontú megközelítés jelentôsen javítja a használhatóságot és a használati hajlandóságot egyaránt, bár a megvalósítás természetesen itt is felvet problémákat. ${ }^{8}$

\section{Könyvtári megközelítés: mi lesz az e-önkormányzati dokumentumokkal?}

Bujdosóné Dani Erzsébet fentebb idézett tanulmányában bemutatja városa könyvtárának a testületi anyagok archiválása és elérhetôvé tétele terén követett gyakorlatát. Elsóként felteszi a kérdést: Hova is sorolhatók be tulajdonképpen ezek a dokumentumok? A helytörténeti osztályozás mellett dönt. Ezt természetesen lehet vitatni, ugyanakkor már maga a kérdés felvetése és megoldása is jelzi, hogy rutintechnikák, szoftverek elóre gyártott sémái itt nem hozhatnak érdemleges eredményeket.

Bujdosóné megállapítja, hogy alig lehet találkozni a teljes testületi dokumentáció elérhetôvé tételével. A néhány példa is arra utal, hogy nincs egységes gyakorlat. Sajnálatos, hogy a szerzó éppen a két legnagyobbat, a Parlamenti és a Budapest Portált nem említi. ('Talán ez is aláhúzza azt az elôzốekben tett megállapítást, hogy ezek az információforrások nincsenek jól látható, szembetúnó módon belinkelve. A szerzó tanulmánya elején rögzíti: a helyi önkormányzati testületek munkájának dokumentációját az önkormányzatiság szerkezetének felállítása óta összesített módon, jegyzókönyvi formában ốrzik meg. A jegyzókönyvek öt példányban készülnek el, amelyekból egy példány a Pest Megyei Közigazgatási Hivatalba, négy pedig a város különbözó intézményeibe kerül. Ezek a következók: a Polgármesteri Hivatal irattára, a címzetes fójegyzó hivatala, a városi levéltár és a városi könyvtár.

A jegyzókönyveket a könyvtárban időrendi sorrendben lefüzik, és ezek a helytörténeti anyag szerves részét képezik. Keresni bennük ebból adódóan nagyon nehézkes, és kizárólag az adott testületi ülés dátuma szerint lehetséges. A megjelenés gyakorisága nem állandó, mivel sokszor elófordul, hogy a havi egy rendszeres testületi ülésen kívül rendkívüli üléseket is tartanak.

Az anyag teljesen feltáratlan, nem felel meg a modern információkeresés feltételeinek, ezért valamilyen formában ezen a téren is meg kellene oldani a minôségi tájékoztatást. A dokumentumok fontos információforrást jelentenek a helytörténeti kutatás, az állampolgári tájékozódás és a közügyek helyi intézése szempontjából egyaránt. A szerzố a továbbiakban ismerteti, hogy a legcélravezetóbb megoldásnak a teljes szövegú adatbázis létrehozását tekintették. Ennek érdekében az XML alapokon nyugvó szövegfeldolgozást és a Dublin Core (DC) metaadatelemeit alkalmazták. Az alábbi munkafolyamatokat írja le:

${ }^{8}$ Bujdosóné Dani Erzsébet 2007: Helyi testületi anyagok leírásának bibliográfiai problémái. Tudományos és Müszaki Tájékoztatás, 54. évf., 11-12. sz., 531-538. 


\section{Szkennelés}

A hagyományos úton elóállított input dokumentumok szkennelése után a papírra vetett szöveg az OCR program segítségével elektronikus formátumúvá alakítható, így azután formázható és szerkeszthetô.

\section{Az optikai karakterfelismertetés (OCR) elókészitése}

A beolvasott oldalakat mindenképpen célszerú valamilyen képszerkesztố programmal elókészíteni az optikai karakterfelismeréshez. A nem kívánatos fekete foltokig bezárólag eltüntethetjük mindazt, amit egészen biztosan nem akarunk felismertetni, továbbá a jobb eredmény érdekében rendbe szedhetjük a nem szigorú rendben feliratozott oldalakat.

\section{Optikai karakterfelismerés és -felismertetés (OCR)}

Az optikai karakterfelismertetéshez a Recognita OmniPage Pro 11 szoftvert használjuk. Az OCR végrehajtása során nyert szöveget tárolása elő́tt korrektúráztathatjuk, továbbá igénybe vehetjük az OmniPage szoftver Intelli'Train szolgáltatását is.

\section{Korrektúrázás}

A korrektor szerepe hasonlít azokhoz a feladatkörökhöz, melyeket például kiadóknál, szerkesztôségeknél vagy nyomdáknál végeznek. Célja, hogy a digitalizálandó eredeti szöveg teljes mértékben megegyezzen az interneten megjelenố szöveggel.

\section{XML kódolás}

A már korrektúrázott forrásanyagot a PSPad szövegszerkesztóbe töltjük be, mert ez ingyenesen rendelkezésre áll. Itt kell lecserélni az ékezetes betúket entitásokra, továbbá itt kell az XML címkéket elhelyezni a kódban. (A PSPad helyett vannak más ingyenes programok is, sốt, az XML szerkesztésére talán nem is a kifejezetten karakteres szerkesztók a legalkalmasabbak, de a célnak jelen esetben ez is megfelel.)

A helyes szintaktikai kódolás ellenórizhetố a felhasznált DTD-vel való összevetéskor, de csak akkor, ha például egy validálásra is képes XML szerkesztốt használunk, a PSPad erre nem alkalmas. A kódolás befejeztével az XML kódot át kell konvertálni HTML formátumúvá.

A munkamegosztást a következók szerint célszerú kialakítani:

- Elsố lépés a meglevô jegyzókönyvek gépre vitele szkenneléssel rtf formátumban. Ez a könyvtárban megoldható.

- Az optikai karakterfelismerés elókészítése és végrehajtása is megoldható a könyvtárosok szaktudásával.

- A korrektúrázás szintén a könyvtárosokra váró feladat.

- A DTD-k kidolgozásában is nagy szerepe van a könyvtárosi munkának, de ez a folyamat az informatikusok és a könyvtárosok közös munkáját igényli.

- Az XML-alapú szövegfeldolgozás az informatikusok feladata.

- A Dublin Core metaadatok elóállítása a könyvtáros feladata, míg azoknak a fejlécbe való behelyezése az informatikusé.

- A kész XML kód lefordítása HTML formátumba a számítástechnikus feladata. 
Azért mutattam be ilyen részletesen a munka elemeit, hogy érzékeltessem: könyvtárosi munkamódszerrel a testületi anyagok elérhetôvé tétele más, az eddig látottaktól (Parlamenti és Budapest Portál) felfogásában eltérô, sokkal inkább használatcentrikus megközelítést igényel, és más végeredményt hozhat. A téma, vagyis a testületi dokumentumok bibliográfiai leírása, rendezése és elérhetôvé tétele nagyon szerteágazó feladat, s láthatóan a hagyományos könyvtárosi és az informatikai szakismeretek együttes felhasználását igényli. Mivel a munka célja teljes szövegú adatbázis létrehozása és az adatbázis interneten való hozzáférésének megoldása, egyik hivatás képviselôinek a kompetenciája sem nélkülözhetố.

\section{A parlament honlapja mint tájékoztatási felület az információszolgáltatás szempontiából}

Az országgyúlés ülései nyilvánosak, s csak kivételes esetben, az alkotmányban meghatározott feltételekkel tartható zárt ülés. (Erre az utóbbi tizenhat év alatt mindössze három alkalommal került sor.) Az ülésekról szó szerinti jegyzókönyv készül, amelyet az országgyúlés a honlapján is közzétesz.

A nyilvánosság elve nemcsak az ülésekre, hanem az országgyúlés tárgyalási anyagaira, dokumentumaira is kiterjed. Az országgyúlés honlapja teljes képet nyújt a parlament munkájáról, s egyúttal megismertet annak „kulisszatitkaival” is. Az információt keresốk megtudhatják, miról tárgyal az országgyúlés, hogyan születnek meg a törvények, milyen kérdéseket, interpellációkat tesznek fel a képviselók, és azt is, hogy egyegy elốterjesztésról hogyan szavazott az országgyúlés. Tájékozódhatnak a parlament múltjáról, a jelen aktualitásairól és a várható eseményekról egyaránt. Ma már nemcsak a plenáris, hanem a bizottsági ülések jegyzókönyvei is elolvashatók az interneten.

Az országgyúlés döntései is nyilvánosak: a törvényeket és a határozatokat a Magyar Köztársaság hivatalos lapjában, a Magyar Közlönyben teszik közzé. Az új törvényi szabályozás értelmében a Magyar Közlöny online ingyenesen hozzáférhetố elektronikus változata is hiteles változatnak tekinthetô. ${ }^{9}$

A nyilvánosság biztosításában az 1994-ben elfogadott házszabály jelentôs szerepet szánt az Országgyứlési Könyvtárnak. Az irományok teljes részletességú elôzetes hozzáférhetôségét biztosító elektronikus futárpostarendszer megalkotása óta azonban a parlamenti honlapon is mindenki számára hozzáférhetô valamennyi elóterjesztés, valamint a plenáris és bizottsági ülések jegyzókönyvei és a szavazási listák is. A könyvtár szerepe az irományok elektronikus tárolása és elérhetôvé tétele tekintetében a „távoli nyilvánosság”, az internetfelhasználók szempontjából csökkent.

Az országgyúlés elnökének 2/2004. számú rendelkezése a parlamenti honlap futárpostájának múködését az alábbiak szerint szabályozza: „Az elektronikus futárpostát - az Országgyúlés Házszabályának keretei között, a képviselók gyors és folyamatos tájékoztatása érdekében - az Országgyúlés elnökéhez benyújtott irományokra és azok

9 2008. évi XXV. törvény az elektronikus információszabadságról szóló 2005. évi XC. törvény módosításáról. 
tárgyalásához kapcsolódó tájékoztató anyagokra és dokumentumokra vonatkozóan kell bevezetni. Az országgyưlési képviselók munkájához szükséges irományok, illetve azok benyújtását is folyamatosan követố listák, továbbá a tájékoztató anyagok és dokumentumok kézbesítésének, megküldésének, hozzáférhetôvé tételének, valamint az azokról történố tájékoztatásnak elsốdleges eszköze a papírkímélő elektronikus futárposta. Az elektronikus futárpostát az országgyúlés honlapján - www.parlament.hu -, a fớmenüból kell múködtetni.

Az országgyúlés honlapja a közcélú magyar internetes oldalak között a legteljesebb körú és legambiciózusabb adatszolgáltatást nyújtja ennek megfelelóen az egyik legöszszetettebb adatgazdálkodási rendszerben. A honlapon megtalálható információkat az állampolgárok egyidejúleg és ugyanolyan terjedelemben kérdezhetik le, mint maguk a parlamenti képviselók. Az adatbázis egy egyszerú és egy összetett keresófelülettel („Irományok egyszerúsített lekérdezése”, ill. „Irományok lekérdezése”), valamint a benyújtott törvényjavaslatok listázásával („Folyamatban levố törvényjavaslatok”) teszi lehetôvé a dokumentumok megkeresését, illetve böngészését.

Az egyes törvényjavaslatok megjelenítésekor nemcsak azok szövegét, a hozzájuk kapcsolódó indoklást és a benyújtásukkal kapcsolatos adatokat találhatjuk meg, hanem azt is, hogy a törvényalkotási folyamatban melyik szinten áll az adott dokumentum, milyen hozzá kapcsolódó módosító vagy egyéb javaslatok léteznek, továbbá - ha sor került a javaslat tárgyalására - szerepel az adott ülés jegyzókönyveihez vezetô ugrópont is. Összességében tehát részletes képet kaphatunk a folyamatok pillanatnyi állásáról. A parlamenti információs rendszer hozzáférhetôvé teszi az országgyúlés munkáját leíró, az üléseken elhangzottakat és történteket szó szerint rögzítő Parlamenti Napló szövegét is - nagyon korlátozottan kereshetố változatban.

Az összetettségból következóen az oldalon való tájékozódás komoly elókészületeket, formanyelvi ismereteket kíván meg. Ezt felismerve, a honlap múködtetôi megpróbálnak segítséget nyújtani az oldal használóinak, méghozzá meglepó módon nem a Help menük szokásos boksz- vagy füljelzéséról, hanem egy „közérdekú információk” jelzésû ikonról indulva. Ez természetesen máris félrevezetố. Az itt megjelenô oldalon az elsố gyakorlati útmutatásként ez olvasható:

„Nézzünk elsố kérdésként egy olyan egyszerú példát, melyben egy törvényjavaslatot szeretnénk megkeresni, amelyról esetleg hallottunk, de nem tudjuk biztosan, hogy létezik vagy egyáltalán benyújtják. Elsóként érdemes a honlap Futárposta címszava alatt keresni és a kormány féléves törvényalkotási programját átnézni. Ebben azt is megtalálják, amit csak késóbb szándékozik benyújtani a kormány, de azt is láthatjuk, hogy mikorra várható és mekkora terjedelmú a tervezett szabályozás. További fontos információ, hogy melyik minisztérium a téma gazdája. A képviselók által kezdeményezett törvényjavaslatokat természetesen nem itt, hanem az irományok címszó felól érhetik el. Hasznos belenézni az ülésterv anyagába is, mely már azt az információt tartalmazza, hogy a javaslatok egyes parlamenti tárgyalási szakaszaira mely ülésnapokon kerül sor. Így például az általános vita, a módosítókról való határozathozatal vagy éppen a zárószavazás.”10

Elsố ránézésre is érzékelhetô a szövegból, hogy olyan emberek írták, akik maguk is részesei a rendszernek, hiszen olyan terminológiát használnak, olyan élethelyzete-

\footnotetext{
${ }^{10}$ Ország Háza [Honlap]: http://www.parlament.hu/pairhelp/keres.htm
} 
ket vizionálnak, amelyek ismerete kevéssé jellemzô az oldal kezdő vagy tájékozódó látogatóira. A felhasználó nézópontjából ez a magyarázó útmutató - a megszokott help oldalaktól távol esố szerkezetével és stílusával - talán kevéssé az aktivitásra, inkább a megállásra ösztönöz. A záró rendelkezésekból egyértelmúen kiderül, hogy az illetékes vezetố az adatbázis múködtetését elsôsorban hivatali, adminisztratív feladatként határozza meg. Ezt természetesen nem is lehet vitatni, de a nyilvánosság elrendelése mellett célszerú lett volna meghatározni valamilyen információgazdálkodási követelményrendszert is. Ez nem történt meg, ami azért is sajnálatos, mert a tartalom valóban értékes és egyedülálló, s elérhetôvé tétele könyvtári, adatgazdálkodási szempontból jelentốs teljesítmény.

Itt jól láthatók az e-kormányzat és az e-demokrácia már említett különbségei: ezeket a fogalmakat a közélet különféle indíttatású és akcióképességú szereplői másképpen értelmezik, mint a döntéshozók. Látható a megközelítés: végül is a tartalom fenn van az interneten, kihelyezték, tehát az adatgazda úgy látja, teljesítette feladatát. A felhasználó viszont teljes funkcionalitásában, teljes tartalomgazdagságában nem tudja használni az oldalt, mivel nem kapja meg hozzá a szükséges és elvárható asszisztenciát. Gyakorlati tapasztalatom, hogy az adatbázis megfelelôen múködik, s egy terjedelmében és sokrétúségében tekintélyes adatvagyont színvonalasan kezel. Maguk a képviselók és a hivatal munkatársai sem használnak más hálózatot. A tájékoztatási felület korrekt, ugyanakkor minden keresési kísérlet megkezdésekor világosan érző́dik a portálon az információs hagyományos nevén: könyvtári - szakember munkájának a hiánya. Nincs kelló eligazodási segédlet az adatbázis kezeléséhez, nincsenek orientáló ismertetések a szövegek típusairól, tartalmi és formai sajátosságairól. Az informatikai rész megfelel a kitûzött feladatnak, az információs rész azonban elmarad a ma elvárt minóségtól. Jelen írásomnak nem lehet célja javaslatok megfogalmazása az országgyúlés honlapjának átalakítására. Kutatói, rendszeres használói nézópontból azonban úgy látom, a közeljövóben szükséges volna a honlap múködtetésével kapcsolatban, fóleg a nyilvánosságra vonatkozó elemeket illetôen megfogalmazni bizonyos szakmai kritériumokat az információmenedzsment tekintetében is. Az adatbázis kezelhetôségének, hozzáférhetôségének, rendezettségének magasabb szintre emelésében, ami erôsíthetné a felhasználók motivációját is, aligha nélkülözhetố a könyvtárosi, archiválási szakértelem.

\section{A kormányzati portál mint informatikai zászlóshajó, könyvtári navigációs müszerek nélkül}

Az e-kormányzat leglátványosabb eleme a kormányzati portál. Közkeletú és valós elnevezése is „Magyarország pont hu”. Az Ügyfélkapu regisztrált, személyazonosságukat hitelesen igazoló felhasználóinak száma a 2009. év elsô felében átlépte a hétszázezret, s ezzel a portál - hagyományos értelemben és elektronikusan is - vitathatatlanul az ország legnagyobb hivatala lett. Egyes ügyforgalomtípusokban szinte teljesen átvette a hivatalok ügyfélkapcsolatainak menedzselését, ezek közül is kiemelkedik az elektronikus adóbevallás. 
A kormányzati portál nemcsak elektronikus tranzakciók lebonyolítására jött létre. Ugyanolyan fontos, sok témakörben akár elóbbre való feladata az állampolgári tájékoztatás, az ügyintézéshez szükséges információellátás; valamint hazánk történelmének, jelenlegi államstruktúrájának, európai státusának bemutatása, dokumentálása. Összefoglalva: az országismeret tudásmenedzsmentje. Ilyen kitekintésben nehezen érthetó, hogy a nagy könyvtári adatbázisok miért nem érhetók el közvetlenül a portálról, még az OSZK vagy az Országgyúlési Könyvtár sem. A ,szolgáltatások A-Z-ig” menüpontban csak a könyvtár kifejezés található meg, ennek ma gyakran használt rokon fogalmait (adattár, archívum, tudásbázis) a rovat nem ismeri. Ennek megfelelóen kimarad a NAVA (Nemzeti Audiovizuális Archívum) és az NDA (Nemzeti Digitális Adattár) is, hogy csak a legnagyobbakat említsem. A könyvtár címszónál végül az OSZK két platformja érhetố el, a Libinfo és a NEKTÁR. Nyilvánvaló, hogy a könyvtári rendszer teljesítốképessége és tudás-disztribútori potenciálja ennek a két szolgáltatói felületnek a megadásával nem érzékeltethetô.

A tájékoztatási kötelezettség szempontjából további hiányosságnak tekinthetjük, hogy a mindennapi élethez szükséges információs bázisok, például a menetrendek, útvonalkeresók, idójárás-jelentések, hírgyújtók sem érhetók el közvetlenül a portálról. Ezeket a szolgáltatásokat így regionális önkormányzati honlapok vagy médiavállalkozások nyújtják. Talán a leginkább kiugró hiányosság a közigazgatási adatvagyon prezentálásának hiánya. Itt elsôsorban a térinformatikára, a digitális város- és közmútérképekre és a demokrácia intézményeinek (önkormányzatok, parlament stb.) dokumentumaira gondolok. Ez az ismeretanyag több helyen a könyvtárakba kerül, onnan elérhetó, tehát már rendszerezett és feltárt formában szerepelhetne a kormányzati portál információhorizontján is.

A kormányzati portál mellett szót kell ejteni a „kis-kormányzati” oldalakról, vagyis a települések saját honlapjairól is. A civil és az üzleti szféra a legintenzívebben az önkormányzatok útján kerül kapcsolatba a közigazgatással. Az állampolgár általában itt találkozik a közigazgatás ügyintézó apparátusával: az okmányirodák, az ügyfélszolgálatok a közvetlen kontaktusfelvétel helyszínei. Maga a virtuális ügyintézés is itt kezdôdik, hiszen az okmányirodákban lehet bejelentkezni az Ügyfélkapuhoz, elektronikus aláíásunkkal igazolva identitásunkat.

Az önkormányzati elektronizáció látványos és többnyire ma már valóban informatív terepét a honlapok, a települések saját hálózati oldalai nyújtják. Ezek a folyamatosan kiérlelődő demokrácia és a korszerú közigazgatás közös platformjaként szolgálnak, és sok szempontból monitorozzák óket a kutatók, informatikai és közigazgatási szakemberek egyaránt. Úgy tûnik ki a beszámolókból, hogy a helyi honlapok - szemben a központi kormányzati oldalakkal - nem annyira az ügyintézés, mint inkább a tájékozódás és a közéletbe való bekapcsolódás fórumaivá válnak.

Ezt a tendenciát állapítja meg az „Elektronikus közigazgatás: éves jelentés 2007” címú tanulmány is. „2007-ben az önkormányzatok szerepe az e-ügyintézésben Magyarországon rendkívül hangsúlytalan volt. Az önkormányzatokon keresztül indított elektronikus tranzakciók szinte nem is játszanak szerepet a Magyarország.hu összes elektronikus tranzakcióját tekintve: 0,15\%-ot adnak ki, azaz még a negyed százalékot sem érik el: öt hónap alatt mindössze alig 30000 tranzakció. Igaz, hogy a MOHU teljes tranzakcióinak java részét az APEH-bevallások adják ki (67\%-ot). Tény, hogy az 
okmányirodák állami feladatokat látnak el, ennek pedig nincs köze az önkormányzati múködéshez - ezért az elóbbi adatok az önkormányzatok elektronikus ügyintézésének csak egy jellemzố részletét mutatják. Jellemzó adat az is, hogy önkormányzati tranzakciók Magyarországon 2007-ben mindössze 24 település önkormányzatától és három önkormányzati társulásból indultak a MOHU felé."11

Az önkormányzati honlapok - reflexszerúen önigazoló - küszködései identitásuk megteremtéséért jól követhetók a nagyobb városok honlapjain. A legelórehaladottabb intelligens városi szolgáltatások meghonosítóiként és múk ödtetốiként általában Szeged, Szombathely és Budaörs portáljait szokták bemutatni. Itt valóban meggyoózók a fejlesztések, az e-ügyintézés és a tájékoztatás szempontjából egyaránt. Míg Szombathely és Budaörs önkormányzati honlapként jelentkezik be a főoldalon, addig Szeged nagyon mértéktartóan, városi portálként: az önkormányzat csak az intézmények felsorolásában kap helyet. Megemlítendó, hogy Szeged a második „mélységi szinten”, kiemelten ad hozzáférést könyvtáraihoz; Budaörs pedig a főoldalon, a legszembetúnóbb helyen jeleníti meg az elektronikus könyvtári boxhoz vezetố ugrópontot (még ha az nem is a könyvtárba, hanem egy elektronikus szöveggyújtemény ugródeszkájához vezet).

Az e-önkormányzat fogalomkörében - tekintettel a közvetlen lakossági kapcsolatra - még hangsúlyosabban jelenik meg az e-ügyintézés igazgatási-eljárási komplexuma. Az elơzó évtizedektól gyökeresen eltérô szolgáltatási kompetenciák és felelôsségek alakulnak ki. Az önkormányzati információszervezés és tudásmenedzsment most formálódó világában átértékelődnek a helyi közigazgatással tartalmilag és szervezetileg is szoros kapcsolatban álló könyvtárak lokalitáseszményei és területi funkciói. Gondoljunk csak a térinformatikára: a betúalapú helytörténeti kiadványok könyvtári bázisának összekapcsolása a sok városi honlapon hozzáférhetố teljes digitális településtérképekkel, panoráma-fotósorozatokkal, video-összeállításokkal - és forgalomfigyelô kamerákkal óriási lehetôségeket rejt magában, de ehhez még kidolgozandó koncepciókra és kísérleti megoldásokra van szükség.

\section{Összefoglaló megállapítások}

Az e-közigazgatás az elektronizációból következó társadalmi átalakulások egyik fő területe, az állampolgárok életét meghatározó sokirányú változások kezdeményezôje és egyben végrehajtója is. Az itt zajló folyamatok kihatnak a közszféra egészére, tehát a könyvtár, a könyvtári rendszer helyét és szerepét folyamatosan vizsgálni szükséges az e-kormányzat és az e-demokrácia jegyében születố kezdeményezések viszonyrendszerében.

Az Európai Unió a könyvtári adatbázisok, elektronikus katalógusok online elérhetôségének biztosítását a tizenkét legfontosabb állampolgári közszolgáltatás egyikeként definiálja, azonos szinten az emberek életének legfontosabb közjogi aktusaival. Ez a szemléletmód még nem tapasztalható a kulturális irányítás, az országos és helyi döntéshozók között, s talán még a könyvtári menedzsment oldaláról sem érzékelhetố elég határozottan.

${ }^{11}$ Molnár Szilárd et. al. 2007: Elektronikus közigazgatás éves jelentés, 2007 [Elektronikus dokumentum], Budapest, ITTK, 44. http://www.ittk.hu/web/docs/ITTK_EKOZIG_2007.pdf 
A tárgyban keletkezố tanulmányok és helyzetjelentések - a web 2.0 mintájára, de említhetjük a könyvtár 2.0 analógiáját is - egyértelmúen az e-kormányzat 2.0 folyamatos térhódítását prognosztizálják. A 2.0 logikájú paradigmaváltás a passzív állampolgárból, a hivatali ügyfélból a viszonyokat alakítani képes résztvevoót formál. Ez az önszervezó és participatív világ egyáltalán nem áll távol mindattól, amit a legfiatalabb állampolgárok olyannyira megszoktak mindennapi online tevékenységeik során. Megteremtôdhet az esélye, hogy átterelő́dnek a közszolgáltatások tranzakciói az állampolgárok által kezdeményezett felületekre, közösségi oldalakra. Kormányzati, önkormányzati szervezésú portálokról az ügyintézés az önépítố tudásoldalakra, a hálózati magatartásmintákat követő weborgánumokra vezérlődik. A könyvtári gyứjtőoldalak, adattárak számára ez azt jelentheti, hogy a kormányzati digitalizáció egy új szakaszában ismeretszervezési innovációkkal bekapcsolódhatnak a közszolgáltatások megújításába.

A magyar e-közigazgatás, de talán a teljes hazai digitális átalakulás egyik legjellegzetesebb virtuális intézménye a kormányzati portál, a „Magyarország pont hu”. Az oldal „Ügyfélkapu” pultja az elektronikus hivatal hazai szinonimájává vált. Könyvtári térvesztésnek, múködtetối oldalról informatikai gondatlanságnak, felhasználói szempontból pedig információveszteségnek tekinthetô, hogy a portálról nincs mód a nagy nemzeti könyvtári adatbázisok elérésére, sốt az elektronikus archívumokhoz sincs közvetlen ugrópont.

Az elektronikus közigazgatás új paradigmái csak professzionális információ- és tudásmenedzsment-komplexumok rendszerbe állításával múködóképesek. Az e-kormányzati stratégiákban és cselekvési tervekben meg is jelenik ez az alapgondolat, kiemelt feladatként fogalmazódik meg az ismeretgazdálkodás hálózati módszereinek és technikáinak alkalmazása. A kormányzati adatvagyon kezelése, kiaknázása és a tudásfolyamatok magas szintû szervezése információs szakemberek, valamint új - és részben átalakuló hagyományos - ismerettároló intézmények közremúködését feltételezi: az e-ügyvitelnél többet jelentố e-ügygondozás kifejlôdése során a nyitottság, az áttekinthetôség és nem utolsósorban a hatékonyság követelményrendszerében a könyvtári kompetenciák szerepének kibővüilése prognosztizálható.

Az internetezốk döntô többsége (83\%) információszerzésre, tájékozódásra használja a világhálót. Nagyon magas (74\%) a szórakozási, kikapcsolódási célból szörfölók aránya is, valamint közel ugyanennyien (70\%) böngészik tanulási, tudásszerzési céllal is az internetet. Az elmúlt években látványosan bơvült a kapcsolattartást szolgáló oldalak és alkalmazások (blogok, fórumok, chat- és közösségi oldalak) száma is, s mindehhez megfelelő tömegbázist jelentenek a hazai internetezók: közel háromnegyedük használja a világhálót a családjával, ismerôseivel való érintkezésre is. Az e-kormányzati szolgáltatások használatának aránya - a többi említett területhez képest - viszonylag alacsonynak számít, az internetezô sokaságon belül huszonkét százalékosra tehetô. A hasznosság megítélése ugyanakkor meglehetốsen pozitív: a közelmúltban egy vizsgálat során a rendszeresen internetezố válaszadók a legtöbb e-kormányzati szolgáltatást 4-es vagy magasabb átlagpontszámmal értékelték egy ötfokozatú skálán. ${ }^{12}$ Ezek az adatok is

${ }^{12}$ Az ICT-piac nagykönyve '08. 2008. Fóbb szereplók, tények és számok a hazai ICT-piacról. Szerk. Sziebig Andrea. Budapest, IT Business Publishing Kft., 70. 
rámutatnak arra, hogy az elektronikus közszolgáltatások iránt nagy a bizalom, az e-közigazgatás platformjainak tudatos használata a „net-intelligencia” részévé vált. Ugyanakkor még mindig kevesen lépnek be az e-hivatal virtuális irodáiba, és ami könyvtári szempontból különösen érdekes, a rendelkezésre álló közadattárak igénybe vétele is ritkább a vártnál függetlenül a tudásbázisok vitathatatlan magas színvonalától. Könyvtári szerepvállalás az állami, önkormányzati szektor adatbázisainak népszerúsítésében, használatra oktatásában bizonyára elôsegítené az e-ügygondozás egyébként bizalommal várt és igényelt meghonosodását.

\section{Irodalom}

Bevezetés az elektronikus közigazgatás ismereteibe. 2007. Tankönyv a köztisztviselók továbbképzéséhez. [Elektronikus dokumentum] Szerk. Köteles Bernadett. Budapest, Kormányzati Személyügyi Szolgáltató és Közigazgatási Képzési Központ. http://www.kszk.gov.hu/ data/cms19112/ekozig_tankonyv.pdf

Budai Balázs Benjámin - Szentkirályi-Holota Szabolcs 2005. Az elektronikus közigazgatás jogi környezete. E-Government tanulmányok. Budapest, E-Government Alapítvány.

Budai Balázs Benjámin - Szakonyi András 2005. Interaktí önkormányzat. Budapest, Mediprint.

Burszán Judit 2005. Ügyintézés elektronikus úton. Ket a gyakorlatban. Budapest, [kiad.] Fơvárosi Közigazgatási Hivatal, Fốvárosi Önkormányzat, Fốvárosi Jegyzók Egyesülete.

Csepeli György - Dessewffy Tibor - Hammer Ferenc - Kitzinger Dávid - Magyar Gábor Monory Mész András - Rozgonyi Krisztina 2007. Közszolgálat a digitális korban. Médiakutató, 5. évf., 2. sz., 7-23. http://www.mediakutato.hu/cikk/2007_02_nyar/01_kozszolgalat_ digitalis_korban/01.html

Csepeli György 2007. Kreatív társadalom. Kritika, 36. évf., 12. sz. 2-4.

Csepeli György 2008. Wikitudás. Kritika, 37. évf. 4. sz. 2-4.

Csepeli György 2009. Nemzeti Digitális Közmú. Tudományos és Mǘszaki Tájékoztatás, 56. évf., 4. sz., 174-177.

Csüllög Krisztina - Varga Anikó 2007. Felmérés a hazai e-közigazgatás lakossági fogadtatásáról. Információs társadalom, 7. évf., 1. sz., 86-96.

Dombi Gábor - Kollányi Bence - Molnár Szilárd 2007. Befogadást az Információs Társadalomba most. Az életminốség, digitális esélyegyenlôség és a társadalmi megújulás Magyarországa. Helyzetkép, legjobb gyakorlatok és akcióterv. [Elektronikus dok.] Budapest, Informatikai Érdekegyeztetô Fórum. http://einclusion.hu/wp-content/uploads/2007/09/einclusion_ inforum.pdf

Karoliny Eszter 2006. Teljes szövegú jogszabályok az interneten - Elektronikus információszabadság és következményei a könyvtárak számára. Tudományos és Múszaki Tájékoztatás, 53. évf., 5. sz., 238-241.

Kerekes Pál 2006. Kormányzati adatbázisok, elektronikus hivatalok tájékoztatási felületei, nemzeti hálózati nagyprojektek. In Információból ïzleti érték - az információbróker környezete és munkája. Szerk. Mikulás Gábor. Budapest, MIBE. 211-219.

Kerekes Pál 2008. A Könyvtár és a digitális gyújtemények helye, szerepe az elektronikus közszolgáltatások rendszerében. Doktori disszertáció. Budapest, ELTE BTK Könyvtártudományi és Informatikai Tanszék. 
Magyar információs társadalom jelentés 1998-2008. 2007. [Elektronikus dokumentum] Budapest, BME-UNESCO Információs Társadalom- és Trendkutató Központ, GKIeNET, MTA Infokommunikációs Jogi Centrum. http://www.ittk.hu/web/docs/ITTK_MITJ_19982008.pdf

Molnár Szilárd - Z. Karvalics László 2004. Közigazgatás az Internet korában - az e-kormányzat kutatói szemmel. Információs Társadalom, 3. évf., 2. sz., 5-23.

Paszternák Ádám - Takács Dániel - Mikulás Gábor 2007. Könyvtár 2.0, avagy közösen vagyunk tudásbirtokosok. Könyv, Könyvtár, Könyvtáros, 16. évf., 9. sz., 10-23. http://www.ki.oszk. hu/3k/e107_plugins/content/content.php?content.83

Szigeti Tamás - Szoboszlai Judit - Vissy Beatrix 2008. Megfelelés az elektronikus információszabadság törvény követelményeinek 2007-2008. [Elektronikus dokumentum] Budapest, Eötvös Károly Közpolitikai Intézet, augusztus. http://www.ekint.org/ekint_files/File/ tanulmanyok/az_e_infoszabadsag_tv_hatalyosulasanak_vizsgalata.pdf

Tózsa István 2008. E-Government - elektronikus közigazgatás. Magyar Tudomány, 169. évf., 7. sz., 833-843.

Z. Karvalics László 2008. Úton a digitális kori kormányzás felé. Budapest, Demos Magyarország. 